\title{
Peranan Internal Public Relations PT Prasadha Pamunah Limbah Industri Dalam Mensosialisasikan Brand PPLI
}

\author{
Oppie Megawarni Suryadi ${ }^{1}$, Shulhuly Ashfahani ${ }^{3}$ \\ ${ }^{1,2,3}$ Sekolah Tinggi Ilmu Komunikasi Indonesia Maju \\ Email correspondent: oppiesuryadi0@gmail.com
}

\begin{abstract}
Abstrak
Fenomena yang peneliti tangkap selama menjalani magang di bagian Public Relations PPLI. Fenomena tersebut menyangkut perubahan brand yang terjadi karena akuisisi perusahaan dan peran Internal Public Relations dalam mensosialisasikan brand tersebut. Tujuan dari penelitian ini adalah untuk mengetahui peranan Internal Public Relations PT Prasadha Pamunah Limbah Industri dalam mensosialisasikan brand PPLI Tahun 2016. Penelitian ini berjalan dengan sebuah pemikiran bahwa seorang Public Relations atau Humas bertugas membina hubungan dengan publik internal, agar citra dan reputasi perusahaan atau organisasi tetap positif di mata publik internal. Penelitian ini menggunakan metode deskriptif kualitatif. Melalui observasi secara langsung dan wawancara dengan beberapa informan yang terkait, maka penulis berhasil memperoleh data berhubungan dengan masalah yang diteliti. Hasil penelitian yang diperoleh adalah bahwa Internal Public Relations mempunyai peranan penting dalam dalam memperkenalkan dan memberitahu citra perusahaan yang baru kepada publik internal di PPLI. Internal Public Relations mempunyai peranan penting dalam menangani perubahan brand WMI ke brand PPLI selain sosialisasi langsung dengan mengadakan rapat pertemuan kepada perwakilan karyawan, PR di PPLI juga melakukan sosialisasi melalui media internal dalam bentuk email blast, surat tertulis dan beberapa selebaran maupun yang terpampang di papan pengumuman. Selain melakukan sosialisasi melalui media internal pihak PR juga terjun langsung dalam mengawasi perubahan logo pada fasilitas di lingkungan kerja.
\end{abstract}

Kata Kunci: brand, internal public relation, sosialisasi.

\begin{abstract}
The phenomenon that the researcher have captured during my internship in the Public Relations section of PPLI. This phenomenon involves brand changes that occur due to company acquisitions and the role of Internal Public Relations in socializing the brand. The purpose of this study was to determine the role of the Internal Public Relations of PT Prasadha Pamunah Industrial Waste in disseminating the PPLI brand in 2016. This research goes with the thought that a Public Relations or Public Relations task is to foster relationships with the internal public so that the image and reputation of the company or organization remain positive in the eyes of the internal public. This study used the descriptive qualitative method. Through direct observation and interviews with several related informants, the authors succeeded in obtaining data related to the problem under study. The results of the research obtained are that Internal Public Relations have an important role in introducing and informing the new company image to the internal public in PPLI. Internal Public Relations has an important role in handling changes in the brand WMI to PPLI brand in addition to direct socialization by holding meetings with employee representatives, PR at PPLI also conducts socialization through internal media in the form of email blasts, written letters, and some leaflets as well as displayed on notice boards. In addition to disseminating information through internal media, the PR is also directly involved in overseeing logo changes to facilities in the work environment.
\end{abstract}

Keywords: brand, internal public relation, socialization. 


\section{Pendahuluan}

Pada era globalisasi saat ini mendorong segala aspek kehidupan menjadi serba kompetitif. Begitu pula dalam segi ekonomi, perusahaan sebagai pelaku kegiatan ekonomi berusaha untuk bekerja lebih keras agar dapat bersaing dengan perusahaan lain. Apabila ada perusahaan yang tidak benarbenar mempertahankan posisinya, cepat atau lambat perusahaan tersebut akan kalah bersaing dan berakhir gulung tikar atau bahkan melakukan akuisisi. Menurut Brealy,dkk akuisisi adalah pengambilalihan perusahaan dengan membeli saham atau aset perusahaan tersebut, namun perusahaan yang dibeli tetap ada dan beroperasi. ${ }^{1}$

Perusahaan yang melakukan akuisisi dapat dipastikan akan melakukan transformasi nilai-nilai organisasi termasuk perubahan identitas (brand) perusahaan. Brand adalah sebuah nama, istilah, desain, simbol atau ciri- ciri yang menunjukkan identitas atau image dari suatu produk atau jasa. Dengan adanya suatu brand maka akan menunjukkan image, nama dan kualitas produk, cara produsen menjalankan bisnis, dan bagaimana produsen meyakinkan konsumennya. Disini brand yang dimaksud adalah logo. Logo dapat berupa simbol seperti "swoosh-nya" Nike, atau dapat merupakan simbolsimbol yang mewakili nama, seperti "Lenovo-nya" Lenovo atau gambar "lengan dan palu-nya". Logo dapat merupakan penggambaran nama atau bagian dari nama yang diperindah seperti lengkungan kuning yang membentuk huruf "M" dalam McDonald's, atau nama-nama yang diperindah dengan tambahan motto atau simbol. ${ }^{2}$

Warna dari logo perusahaan berkaitan erat dengan makna konsumen yang melihatnya. Sebuah logo perusahaan mengandung makna, dan makna tersebut memberikan penafsiran yang kuat dari konsumen bahwa karakter atau identitas perusahaan bisa digambarkan melalui warna dari sebuah logo. Logo mampu memberikan konsepsi dan makna tersendiri bagi perusahaan maupun perorangan yang menggunakannya, baik itu makna yang bersifat negatif maupun positif. ${ }^{3}$

Sosialisasi logo dan slogan brand perusahaan merupakan salah satu dari kegiatan Internal Public Relations. Internal Public Relations merupakan suatu bagian dari Public Relations (PR) yang bertugas membina hubungan dengan publik internal, agar citra dan reputasi perusahaan atau organisasi tetap positif di mata internal public. Salah satu kegiatan Internal Public Relations yaitu, memberikan penerangan kepada karyawan mengenai suatu kebijakan perusahaan yang bersifat objektif serta menyangkut kepada berbagai aktifitas rutin perusahaan, juga menjelaskan mengenai perkembangan perusahaan tersebut termasuk proses sosialisasi perubahan logo maupun tagline brand perusahaan. Kutipan tersebut mempertegas bahwa internal branding penting dan perlu untuk dilakukan oleh perusahaan. Terutama bagi anggota organisasi atau karyawan yang nantinya berhadapan langsung dengan pembeli, mereka dituntut untuk bersikap on brand karena mereka merupakan garda depan atau cerminan perusahaan yang dirasakan langsung oleh konsumen. ${ }^{4}$

Salah satu perusahaan yang melakukan rebranding karena akuisisi adalah PT Carrefour Indonesia, setelah resmi dibeli saham kepemilikannya oleh PT Trans Retail dibawah CT Corp dengan harga Rp. 7,2 Triliun tahun 2012. PT Trans Retail secara bertahap akan mengganti seluruh nama pusat perbelanjaan Careffour menjadi Transmart. Indira Manopo selaku Manager Marketing dan Customer Engagement PT Trans Retail mengungkapkan, pergantian logo tersebut direncanakan rampung pada tahun 2019. Di tempat terpisah direktur utama PT Trans Retail Shafei Samsudin mengatakan, untuk membuka gerai baru dibutuhkan investasi 100 miliar rupaih. Dana tersebut dibutuhkan untuk infrastruktur dan isi gerai. Hal ini membuktikan bahwa sosialisasi logo bukan lah yang mudah karena harus mempersiapkan dana yang cukup besar dan memakan waktu yang tidak lah sebentar. ${ }^{5}$

Perusahaan lainnya yang melakukan akuisisi karena ketatnya persaingan dan meningkatnya pesaing - pesaing baru adalah Waste Management Indonesia (WMI) dibawah perusahaan induk Modern Asia Environmental Holdings (MAEH) perusahaan pengelola limbah industri asal Amerika resmi diakuisisi oleh Dowa Ecosistem perusahaan asal Jepang dengan brand nya Prasadha Pamunah Limbah Industri (PPLI) tahun 2009. Dowa Ecosistem meng-akuisisi MAEH sebagai upaya 
mempertahankan eksistensi perusahaan pengelola limbah di Indonesia. Selaras dengan upaya pemerintah guna menjaga kelestarian alam dan misi Dowa Ecosistem yang mendedikasikan untuk manajemen dan daur ulang lingkungan, sampai saat ini Dowa Ecosisitem dengan brand nya PPLI menjadi perusahaan pengelola limbah terintegrasi terbesar dan satu-satunya yang mempunyai badan izin untuk memproses limbah B3 (bahan berbahaya dan beracun) di Indonesia. ${ }^{6}$

PT Prasadha Pamunah Limbah Industri (PPLI), satu-satunya perusahaan pengelola limbah terpadu dan ramah lingkungan di Indonesia, dianugerahi penghargaan Keselamatan dan Kesehatan Kerja tingkat Nasional oleh Pemerintah Indonesia melalui Menteri Tenaga Kerja dan Transmigrasi pada hari Senin 24 Mei 2010 di Jakarta.

Dowa Ecosistem mengganti logo WMI berupa simbol nama perusahaan Prasadha Pamunah Limbah Industri yang diakronimkan menjadi "PPLI". Pergantian logo adalah bukan perkara mudah terlebih untuk perusahaan besar, membutuhkan banyak proses untuk menjadikan logo atau brand tersebut dikenal baik di mata umum (eksternal) dan khususnya dalam perusahaan itu sendiri (internal). Dengan adanya pergantian logo tersebut maka perlu adanya upaya sosialisasi terkait perubahan tersebut. Sosialisasi dalam perubahan logo yang dilakukan PPLI membutuhkan peranan dari PR dalam memperkenalkan dan memberitahu citra perusahaan yang baru. Seperti yang diungkapkan Kriyantono "Ada pun strategi yang dilakukan PR merupakan tujuan PR agar citra perusahaan tersebut positif di mata publik".

Citra perusahaan (corporate image) bukan hanya dilakukan seorang PR sendirian, tetapi perilaku seluruh unsur perusahaan (karyawan, manager, dan lainnya) ikut andil dalam pembentukan citra ini, baik disadari atau tidak.

Berdasarkan latar belakang yang diuraikan diatas, maka penulis tertarik untuk mengetahui lebih dalam mengenai peran Internal Public Relations dalam mensosialisasikan brand yang tercipta karena akuisisi di PT Prasadha Pamunah Limbah Industri. Dengan pertimbangan tersebut peneliti mengambil judul :"Peranan Internal Public Relations Pt Prasadha Pamunah Limbah Industri Dalam Mensosialisasikan Brand PPLI Tahun 2016.

Tujuan dari penelitian ini adalah untuk mengetahui peranan Internal Public Relations PT Prasadha Pamunah Limbah Industri dalam mensosialisasikan brand PPLI Tahun 2016”.

\section{Metode}

Pada penelitian ini, penulis menerapkan deskriptif kualitatif dengan cara melakukan penelitian langsung terhadap PT. Prasadha Pamunah Limbah Industri. Yaitu mencari informasi yang sebanyakbanyaknya dari bagian Public Relations (PR) mengenai peranannya dalam perusahaan dan dalam mensosialisasikan brand PPLI tahun 2016. Penulis mulai dari melakukan observasi ke lapangan langsung, melihat kegiatan-kegiatan yang ada, mengumpulkan data dan menganalisanya. Peneliti menggunakan Teknik Purposive Sampling. Purposive Sampling adalah salah satu teknik sampling non random sampling dimana peneliti menentukan pengambilan sampel dengan cara menetapkan ciri-ciri khusus yang sesuai dengan tujuan penelitian sehingga diharapkan dapat menjawab permasalahan penelitian. ${ }^{8}$

Teknik pengumpulan data yang digunakan adalah observasi partisipan, yaitu peneliti terlibat dalam kegiatan yang dilakukan oleh subjek penelitian dan sumber informasi penelitian. Kemudian dalam penelitian ini, pengumpulan data diperoleh dari data primer dan data sekunder. ${ }^{17}$

Data primer diperoleh melalui wawancara dangan para informan atau narasumber, wawancara menurut Kamus Besar Bahasa Indonesia yaitu, tanya jawab dengan seseorang yang diperlukan untuk dimintai keterangan, atau pendapatnya mengenai suatu hal. Wawancara adalah percakapan dengan maksud tertentu. Percakapan itu dilakukan oleh dua pihak, yaitu pewawancara (interviewer) yang mengajukan pertanyaan dan terwawancara (interviewee) yang memberikan jawaban atas pertanyaan itu.9 
Pada penelitian ini data primer diperoleh melalui wawancara dengan masing- masing informan sesuai jabatan dan kewenangan pada bagian PR PT. Prasadha Pamunah Limbah Industri.

Observasi adalah pengamatan yang dilakukan secara sengaja, sistematis, mengenai fenomena sosial dengan gejala-gejala psikis untuk kemudian dilakukan pencatatan. Teknik ini dilakukan untuk mengetahui kegiatan yang dilakukan oleh pihak PR dalam menangani kasus ini di tengah-tengah perusahaan. ${ }^{10}$

Sementara dalam penelitian ini data sekunder diperoleh melalui buku, artikel,website, data Surat Keputusan Perusahaan, serta pengamatan langsung terhadap bagian PR dengan media yang digunakan oleh bagian PR itu sendiri.

Dalam penelitian kualitatif, yang menjadi instrumen penelitian atau alat penelitian adalah penulis sendiri. Dalam hal ini Nasution menyatakan seperti dalam kutipan di bawah ini: "Dalam penelitian kualitatif tidak ada pilihan lain daripada menjadikan manusia sebagai instrumen penelitian utama. Alasannya adalah bahwa segala sesuatunya belum mempunyai bentuknya yang pasti. ${ }^{11}$

Oleh karena itu, penulis sebagai instrumen harus divalidasi, seberapa jauh penulis kualitatif siap melakukan penelitian dengan menggunakan pedoman wawancara yang selanjutnya terjun ke lapangan". Instrumen penelitian yang digunakan dalam penelitian ini adalah peneliti sebagai instrumen utama didukung oleh pedoman wawancara (interview guide), yaitu pertanyaan yang memokok sehingga dapat dikembangkan dan diperdalam di lapangan untuk mengumpulkan data. Selain itu, juga dipakai catatan lapangan (field notes) yakni untuk mencatat apa yang didengar, dilihat, dan dipikirkan dalam kaitannya dengan pengumpulan data di lapangan.

Instrumen penelitian yang digunakan dalam penelitian ini adalah peneliti sebagai instrumen utama didukung oleh pedoman wawancara (interview guide), yaitu pertanyaan yang memokok sehingga dapat dikembangkan dan diperdalam di lapangan untuk mengumpulkan data. Selain itu, juga dipakai catatan lapangan (field notes) yakni untuk mencatat apa yang didengar, dilihat, dan dipikirkan dalam kaitannya dengan pengumpulan data di lapangan. Dalam penelitian kualitatif, instrumen utamanya adalah manusia, karena itu yang diperiksa adalah keabsahan datanya. ${ }^{12}$

Terdapat beberapa cara pengujian kredibilitas data salah satunya adalah Teknik triangulasi. Teknik triangulasi adalah menjaring data dengan berbagai metode dan cara dengan menyilangkan informasi yang diperoleh agar data yang didapatkan lebih lengkap dan sesuai dengan yang diharapkan.

Terdapat triangulasi sumber, triangulasi teknik pengumpulan data, dan waktu. Triangulasi sumber dilakukan dengan cara mengecek data yang telah diperoleh melalui beberapa sumber, triangulasi teknik dilakukan dengan cara mengecek data kepada sumber yang sama dengan teknik yang berbeda, dan triangulasi waktu dilakukan dengan cara melakukan pengecekan dengan wawancara, observasi atau teknik lain dalam waktu atau situasi yang berbeda.

Pada penelitian ini peneliti menggunakan Teknik triangulasi waktu dimana uji kredibilitas dilakukan dengan cara wawancara dan observasi dalam waktu yang berbeda.

\section{Hasil \\ Peranan Internal Public Relations PT Persadha Pamunah Limbah Industri Dalam Mensosialisasikan Brand PPLI Tahun 2016}

Setelah penulis melakukan penelitian dengan menggunakan teknik pengumpulan data melalui observasi secara langsung dan wawancara dengan beberapa informan yang terkait langsung, maka penulis berhasil memperoleh data berhubungan dengan masalah yang diteliti.

Berdasarkan data yang diperoleh langsung pada lokasi penelitian, maka dalam bab ini penulis akan memaparkan sejumlah hasil penelitian tentang "Peranan Internal Public Relations PT Prasadha Pamunah Limbah Industri Dalam Mensosialisasikan Brand PPLI Tahun 2016" seperti yang penulis uraikan di bawah ini: 
PT. Prasadha Pamunah Limbah Industri atau disingkat PPLI merupakan satu-satunya perusahaan swasta yang menyediakan tempat pengelolaan limbah industri terintegrasi. Perusahaan yang beralamat pusat di Jl. Raya Nambo No. 1 KM 7 - Desa Nambo Kecamatan Klapanunggal - Bogor 16820 ini sudah 24 tahun beroperasi melayani pengelolaan limbah industri. Sesuai dengan tag line nya yaitu 4R : Reduce, Reuse, Recycle and Recovery atau dalam bahasa Indonesia berarti Mengurangi, Memakai Kembali, Mendaur Ulang, dan Pemulihan. PPLI berusaha berkontribusi untuk Indonesia yang lebih baik.

Untuk mencapai titik pada saat ini PPLI melewati proses yang cukup panjang, beberapa kali akuisisi dan perubahan brand perusahaan pun sempat dirasakan. Seperti yang dijelaskan oleh Ibu Arum Tri Pusposari selaku Manager Public Relations yang menjadi Informan 1 dalam penelitian ini,

"Awal PPLI berdiri itu tahun 1994 dulu namanya Pusat Pengelolaan Limbah Industri dibawah Bimantara Grup kemudian tahun 2000 dibeli oleh Modern Asia Enviroment Holdings (MAEH) perusahaan Amerika dengan brand Waste Management Internasional (WMI). Sampai dengan tahun 2009 MAEH diakuisisi oleh DOWA Ecosistem dibawah DOWA Holdings perusahaan Jepang. Walaupun beberapa kali sempat berubah induk perusahaan namun nama PT nya tetap sama yaitu PPLI hanya brand nya saja yang berubah. Setelah diakuisisi oleh DOWA Ecosistem brand WMI kembali berubah menjadi PPLI yang relauncing brand pada bulan Oktober 2014".

Informan 1 kembali menjelaskan alasan PPLI beberapa kali mengalami akuisis, bahwa:

"Karena pure bisnis jadi memang pemiliknya yg saya tau mau mengembangkan bisnis ke tempat yang lain jadi karena PPLI ini sudah berjalan nah beliau ingin menjual ini biar bisa mengembangkan bisnis di negara berkembang lainnya misal Myanmar atau di tempat lain. Lalu ditawarkan ke perusahaan Jepang yg sudah 120 tahun bergerak di bidang tambang tapi 20 tahun terakhir mereka terlibat juga di bidang Waste Management lalu mereka tertarik mengembangkan bisnisnya maka itu dibelilah PPLI".

PPLI memiliki salah satu divisi, yakni divisi Public Relations Departement yang merupakan salah satu divisi yang berada pada posisi top management, yakni dengan garis perintah langsung dari Direktur Utama. Arum Tri Pusposari selaku Manager Public Relations mengutarakan bahwa:

"Public Relations di PPLI termasuk departement yang baru, dahulu disebutnya yaitu Communication and Goverment Relations Departement dibuat tahun 2007. Selain Communication and Goverment Relations ada juga bagian Community Relations yang bertugas mengurus CSR. Untuk tugas Communication and Goverment Relations Departement mengurus ke pemerintah pusat, KLHK, media. Tahun 2012 Communication and Goverment Relations Departement berubah nama menjadi Public Relations Departement yang dibawahi langsung oleh Direktur Utama”.

PR bertugas membina hubungan baik dengan publik eksternal dan internal, agar citra dan reputasi perusahaan atau organisasi tetap positif. Sebagaimana Informan 1 menjelaskan tugas dari PR di PPLI.

"Tugas PR di PPLI yaitu, mengkomunikasikan pesan kepada eksternal dan internal. Contohnya: external (media, pemerintah) membina hubungan yang baik untuk membangun citra. Kalau internal yaitu memberikan informasi kepada seluruh karyawan mengenai segala sesuatu yang berhubungantentang perusahaan. menyalurkan informasi bisa bermacam-macam bentuknya, seperti newsletter, event management, email, buletin board, dll".

Termasuk apabila ada kebijakan baru tugas PR yang mensosialisasikan kepada seluruh karyawan. Hal ini juga disampaikan oleh Alvian Dwi Yulianto selaku Asisten Manager Public Relations di PPLI yang menjadi Informan 2 dalam penelitian ini.

"PR internal yang ada di PPLI mempunyai peran sebagai penghubung antara manajemen dengan karyawan jadi setiap ada informasi mengenai perusahaan dari manajemen seperti kebijakan baru atau ada departemen yang mendapat penghargaan itu kita sampaikan kepada seluruh karyawan".

Dalam kaitannya mengenai sosialisasi rebranding WMI ke PPLI tahun 2014 Informan 2 kembali memperjelas penyaluran informasi kepada seluruh karyawan, bahwa: 
"Sosialisasi mengenai pergantian logo disalurkan menggunakan media internet yaitu email blast. Kami menghimbau kepada seluruh karyawan semua yang bersangkutan dengan WMI harus diganti beserta atribut yang tercantum baik di gedung, kendaraan, seragam, kop surat, dll".

PR melakukan kegiatan komunikasi yang berhubungan dengan hal-hal yang berkaitan dengan strategi, baik kearah luar (eksternal) maupun kearah dalam (internal). ${ }^{16}$

Strategi PR internal dalam sosialisasi brand selain melalui media juga dibutuhkan komunikasi langsung terhadap karyawan seperti yang digunakan oleh PR PPLI yaitu membuka forum diskusi. Hal ini dijelaskan oleh Informan 1, bahwa:

"Dalam mensosialisasikan brand kepada internal kita lakukan pengumpulan supervisor dan manager dan menginfokan bahwa brand kita akan diganti jadi kita buka seperti diskusi forum. Proses rebranding saya mengumpulkan semua departemen khususnya transport dan maintenance jadi armada- armada dan seragam harus sudah tidak ada lagi, kita ada target 3 bulan untuk atribut WMI sudah harus diganti dengan logo PPLI".

Dalam mengganti suatu brand bukan lah perkara yang mudah harus ada perencanaan yang matang agar tujuan dari rebranding tersebut dapat tercapai. Seperti yang dijelaskan oleh Informan 2, bahwa:

"Perencanaanya cukup panjang jadi pertama kita pahami dulu situasi yang terjadi ini diperlukan untuk ke tahapan selanjutnya yaitu menentukan tujuan. Nah tujuan dari rebranding ini apa nih... yaitu bisa sukses mengganti logo dan atribut WMI menjadi PPLI seutuhnya. pertama yaa logo dulu deh kalau image kan nanti mengikuti sejalan dengan logo sudah terganti semua otomatis orangorang pasti sudah tertanam image PPLI. Karean mengganti logo itu saja bukan perkara mudah loh.. lalu tahap selanjutnya menentukan bagaimana nih cara sosialisasinya, kalau kita menggunakan email blast dan buka diskusi forum, dengan departemen lain dari situ ketauan apa saja yang akan diganti, dirubah, diperbaharui, baru deh nanti kita ajukan ke bagian pengadaan. Kalau sudah ok baru kita implementasikan".

Strategy Rebranding tersebut mendapatkan tanggapan yang cukup baik dari dari internal. Seperti yang disampaikan oleh Radinka Putra selaku Manager Maintenance yang menjadi Informan 3, mengatakan:

"Penyampaian perubahan logo WMI menjadi PPLI cukup baik dimana setelah dilakukan sosialisasi oleh tim PR divisi kami maupun divisi lain langsung ikut berkontribusi mengganti atribut yang masih tertera logo WMI menjadi logo PPLI".

Kegiatan internal perusahaan juga dilakukan untuk memberikan informasi bagi karyawan perusahaan sehingga tujuan perusahaan secara keseluruhan dapat diketahui oleh karyawan dan memperjelas tugas-tugas yang harus dilakukan oleh karyawan. Hal serupa juga disampaikan oleh Dewi Putri selaku staff accounting yang menjadi Informan 4, bahwa :

"Sosialisasi berjalan dengan lancar, kita diinformasikan dari management mengenai akuisisi dan juga perubahan brand menjadi PPLI sudah sangat jelas. Penginformasian yang jelas ini memang yang dibutuhkan karyawan sehingga kita tidak perlu bertanya- tanya".

Strategi yang dilakukan oleh PR PPLI merupakan bagian dari proses komunikasi yang dilakukan perusahaan kepada publik internal. Strategi dalam proses komunikasi tersebut sangat mempengaruhi proses penyebaran pesan yang ingin disampaikan dengan harus diarahkan dengan tingkat ketepatan yang tinggi agar sasaran dan tujuan dapat tercapai.

\section{Pembahasan}

\section{Peranan Internal Public Relations PT Persadha Pamunah Limbah Industri Dalam Mensosialisasikan Brand PPLI Tahun 2016}

Kedudukan PR dan kewenangan petugasnya dalam organisasi tidak selalu dapat dinyatakan dengan tegas. Menurut John Tondowijoyo dalam Mukarom dan Laksana, "Jika humas diakui sebagai 
jajaran kebijakan pimpinan, humas harus berada langsung di bawah direksi. Humas harus mampu menyampaikan kebijaksanaan pimpinan sehingga ia harus langsung berada di pihak yang berhubungan dengan pimpinan seluruh jajaran manajemen. ${ }^{13}$

Hal ini sesuai dengan apa yang dijalankan oleh PPLI, dengan menempatkan PR pada garis perintah langsung di bawah Direktur Utama. Kedudukan PR dalam organisasi yang dibuat seperti ini dianggap sudah ideal karena dapat memfokuskan fungsi humas sebagai jembatan antara perusahaan dengan publiknya, baik publik internal dan atau publik eksternal, sehingga informasi yang diberikan oleh perusahaan maupun feedback yang diberikan oleh publik dapat dicapai dengan maksimal.

Dalam menjalankan tugasnya, publik sebagai sasaran kegiatan humas dibagi menjadi publik internal dan publik eksternal. Sebagaimana diungkapkan oleh Iriantara bahwa untuk memudahkan pemahaman, publik dalam PR biasanya dikategorikan menjadi publik internal dan publik eksternal. Publik internal adalah publik yang berada di dalam lingkungan organisasi sedangkan publik eksternal adalah publik yang berada di luar organisasi. Namun, baik publik yang berada di dalam maupun di luar organisasi sama-sama memengaruhi dan dipengaruhi oleh kegiatan organisasi. Publik internal misalnya karyawan, manajemen dan pemegang saham. Sedangkan publik eksternal misalnya lembaga pemerintah, pelanggan, pemasok, bank, media/pers dan komunitas. ${ }^{14}$

Seperti yang diutarakan oleh Informan 1, PPLI melalui divisi Public Relations yang memiliki sasaran kegiatan publik internal perusahaan, seperti melakukan penyebaran informasi bagi karyawan perusahaan. Pembagian tugas dan tanggung jawab terhadap publik perusahaan sangat bergantung pada kebutuhan perusahaan itu sendiri, karena publik internal pada setiap perusahaan berbeda-beda. Umumnya, salah satu sasaran kegiatan PR internal perusahaan adalah menghubungkan komunikasi antar manajemen dan karyawan agar publik internal mengetahui apa yang sedang terjadi dalam perusahaan dan manajemen juga mengetahui apa yang sedang terjadi pada publik internal.

Peranan PR Internal dalam perusahaan diwujudkan melalui kegiatan-kegiatan internal yang berhubungan dengan pengembangan perusahaan. Kegiatan tersebut sangat bermanfaat, baik bagi perusahaan maupun publik internal perusahaan. Kegiatan internal yang diadakan dapat memberikan dampak positif bagi karyawan dan perusahaan karena kegiatan tersebut bertujuan untuk meningkatkan motivasi karyawan dan meningkatkan kepercayaan terhadap perusahaan. ${ }^{13}$

Kegiatan internal perusahaan juga dilakukan untuk memberikan informasi bagi karyawan perusahaan sehingga tujuan perusahaan secara keseluruhan dapat diketahui oleh karyawan dan memperjelas tugas-tugas yang harus dilakukan oleh karyawan. Contoh kegiatan internal yang dilakukan PR dalam suatu perusahaan adalah special event, sosialisasi kebijakan, dan kegiatan lainnya, dengan menyedakan informasi melalui forum komunikasi. ${ }^{13}$

Penjelasan tersebut sesuai dengan yang dilakukan oleh PR di PPLI, sebagaimana saat PPLI melakukan proses rebranding. Dimana divisi PR melakukan sosialisasi kapada karyawan melalui forum diskusi.

Terdapat media yang dapat digunakan untuk melaksanakan kegiatan publikasi yaitu dengan media audio, media visual, dan media audio-visual. Berikut peneliti paparkan media publikasi. ${ }^{15}$

\section{Media audio}

Dengan media audio ini dimaksudkan agar informasi yang disampaikan dapat ditangkap dengan indera telinga, atau tegasnya yang dapat didengar misalnya: radio, piring hitam, tape recorder, telepon, wawancara, konferensi pers dan lain-lainnya.

\section{Media visual}

Dengan media visual ini dimaksudkan sebagai media yang dipergunakan untuk mengadakan hubungan dengan public, yang dapat ditangkap dengan indera mata. Misalnya seperti surat kabar, 
pameran-pameran foto, slide, buletin, pamflet, lambang, bendera, karikatur, gambar skema organisasi dan lain- lain.

\section{Media audio-visual}

Dengan media audio-visual ini dimaksudkan sebagai media yang menyiarkan "berita" yang dapat ditangkap baik dengan indera mata maupun dengan indera telinga. Misalnya televisi, film dan lainlainnya.

Penjelasan tersebut sesuai dengan yang dilakukan oleh PR di PPLI untuk media publikasi PR di PPLI menggunakan Media Audio saat melakukan konfrensi pres dengan media, menggunakan Media Visual yaitu melalui email blast, selebaran, papan pengumuman, dan menggunakan Media audio- visual melalui TV internal untuk menginformasikan sosialisasi brand PPLI kepada karyawan.

PR di PPLI juga melakukan pemetaan terhadap tujuan yang akan dilakukan, tujuan ini yang nantinya akan menjadi strategi dalam melakukan kegiatan sosialisasi brand di PPLI.

Strategi yang dilakukan oleh internal PR PPLI merupakan bagian dari proses komunikasi yang dilakukan perusahaan kepada publik internal. Hal serupa disampaikan oleh Cutlip dan Center dalam Mukarom dan Laksana, bahwa terdapat empat tahap proses komunikasi yaitu pengumpulan fakta, perencanaan, komunikasi dan evaluasi. ${ }^{13}$

Penerapan strategi yang dilakukan PPLI juga telah sesuai dengan model perencanaan humas yang dijelaskan dalam Anggoro, yakni salah satu model perencanaan humas yang disebut sebagai "model enam langkah" yang sudah diterima secara luas oleh para praktisi humas profesional. Strategi dalam proses komunikasi tersebut sangat mempengaruhi proses penyebaran pesan yang ingin disampaikan dengan harus diarahkan dengan tingkat ketepatan yang tinggi agar sasaran dan tujuan dapat tercapai.

\section{Kesimpulan}

Berdasarkan hasil penelitian mengenai Peranan Internal Public Relations PT Prasadha Pamunah Limbah Industri dalam mensosialisasikan brand PPLI Tahun 2016, maka dapat disimpulkan bahwa Internal Public Relations mempunyai peranan penting dalam menangani perubahan brand WMI ke brand PPLI selain sosialisasi langsung dengan mengadakan rapat pertemuan kepada perwakilan karyawan, PR di PPLI juga melakukan sosialisasi melalui media internal dalam bentuk email blast, surat tertulis dan beberapa selebaran maupun yang terpampang di papan pengumuman. Selain melakukan sosialisasi melalui media internal pihak PR juga terjun langsung dalam mengawasi perubahan logo pada fasilitas di lingkungan kerja.

Peran dari Public Relation (PR) di PPLI yang mewakili perusahaan dalam memberi segala informasi kepada seluruh internal, PR memiliki andil dalam menciptakan komunikasi dua arah serta menjaga agar saluran komunikasi tetap terbuka untuk publik internal perusahaan terutama kepada seluruh karyawan agar tetap menjaga stabilitas dan kinerja dengan adanya peruubahan yang terjadi. Informasi akan selalu diberikan agar menciptakan citra positif bagi perusahaan.

\section{References}

1. ASHAFAHANI, Shulhuly. Shulhuly Ashfahani KAP Antara Pimpinan Dan Karyawan. 2018

2. Brealy dkk. Merger dan Akuisisi: Pengertian, jenis, Alasan, Kelebihan dan kekurangan Merger dan Akuisisi. (Online) (http://jurnal- sdm.blogspot.com/2009/07/merger-dan-akuisisi- pengertian-jenis.html) diakses 20 Desember 2016.

3. Fatimah, Fatimah. "Komunikasi Persuasif Agen Asuransi Dalam Merekrut Calon Agen (Studi4. Hynes. Colour and meaning in corporate logos: An empirical study. Journal of Brand Management 16(8):545-555. July 2009.

4. Danandjaja. Peranana Humas dalam Perusahaan. Yogyakarta: Graha Ilmu; 2011.

5. Samsudin S. Manajemen Sumber Daya Manusia. Bandung: Pustaka Setia; 2009. Diakses dari situs online (http://www.responsiblecare-indonesia.or.id/ diakses Tgl. 20 Desember 2016. 


\section{JIKOM \\ Jurnal Ilmiah Komunikasi}

Volume 12, No.02, Juli. 2020

6. Kriyantono. Teknik Praktis Riset Komunikasi. Jakarta: Kencana; 2012.

7. Arikunto. Metode Penelitian Kualitatif. Jakarta: Bumi Aksara; 2006.

8. Moleong. Metode Penelitian Kualitatif, Edisi Revisi. Bandung: PT Remaja Rosdakarya; 2015.

9. Subagyo. Metodologi Penelitian Dalam Teori Dan Praktek. Jakarta: Rineka Cipta; 2011.

10. Sugiyono. Metode Penelitian Pendidikan Kualitatif, Kuantitatif, dan R\&D. Bandung: Afabeta; 2015.

11. Dwi L. Metode Penelitian Kombinasi (Mixed Methods). Bandung: Alfabeta; 2012.

12. Mukarom \& Laksana. Manajemen Public Relation (Panduan Efektif pengelolaan Hubungan Masyarakat). Bandung: CV Pustaka Setia; 2015.

13. Iriantara. Manajemen Strategis Public Relations. Jakarta: Ghalia; 2013.

14. Widjaja. Komunikasi: Komunikasi dan hubungan masyarakat. Jakarta: Bumi Aksara; 2010. 